\title{
水系洗浄剤向け過熱水蒸気式高速乾燥装置の開発
}

\author{
長 伸朗 ${ }^{\mathrm{a}}$, 瀬戸口 裕嗣 $^{\mathrm{b}}$, 安藤 和広 $^{\mathrm{b}}$, 永井 敬大 ${ }^{\mathrm{c}}$ \\ ${ }^{a}$ 中部電力株) 技術開発本部 エネルギー応用研究所 ( $\mathbf{T} 459-8522$ 名古屋市緑区大高町字北関山 20-1) \\ ${ }^{\mathrm{b}}$ (侏) CJV インターナショナル ( ⿳ 459-8001 愛知県名古屋市緑区大高町下塩田 18) \\ c 侏大同（５ 507-0812 岐皁県多治見市下沢町 3-8)
}

\section{Development of Rapid Dryer Using of Super-heated Steam}

\section{Noburo OSA ${ }^{\mathrm{a}}$, Hirotsugu SETOGUCHI ${ }^{\mathrm{b}}$, Kazuhiro ANDO $^{\mathrm{b}}$ and Takahiro NAGAI ${ }^{\mathrm{c}}$}

\footnotetext{
${ }^{a}$ Energy Applications R\&D Center, Chubu Electric Power Co., Inc.(20-1, Aza Kitasekiyama, Odaka-cho, Midori-ku, Nagoya-shi, Aichi 459-8522)

${ }^{\mathrm{b}}$ CJV International Co., Ltd.(18, Shimoshiota, Odaka-cho, Midori-ku, Nagoya-shi, Aichi 459-8001)

${ }^{c}$ Daido Co., Ltd.(3-8, Shimozawa-cho, Tajimi-shi, Gifu 507-0812)
}

Keywords : Super-Heated Steam, Dryer, High Speed, Complex Shape Object

\section{1.はじめに}

自動車部品工場などで加工を終えた機械部品は, 表面の切 削油や切粉等を洗浄した後, 乾燥させて出荷している。その 洗浄の際には, 従来は引火性があり有毒な溶剂系洗浄剤が用 いられるのが一般的であったが, 近年は環境性, 安全性およ びコストの面で, 水系洗浄剤が採用されつつある。

しかしながら, 水系洗浄剤は揮発性の高い溶剤系洗浄剤に 比べ, 乾燥工程に時間を要するという難点があるため, 工場 で水系洗浄剤を導入したくても断念せざるを得ないことが 多々あり, 水分を高速に取り除く乾燥技術が急務の課題で あった。

そこで, 洗浄後の金属部品を短時間で乾燥できる過熱水蒸 気式高速乾燥装置を開発した。

\section{2. 背 景}

\section{1 機械部品の洗浄方法}

従来の水系超音波洗浄設備の外観写真を図 1 に示す。図 2 に示すように, 洗浄設備は, 洗浄・すすぎ・乾燥の 3 種類の

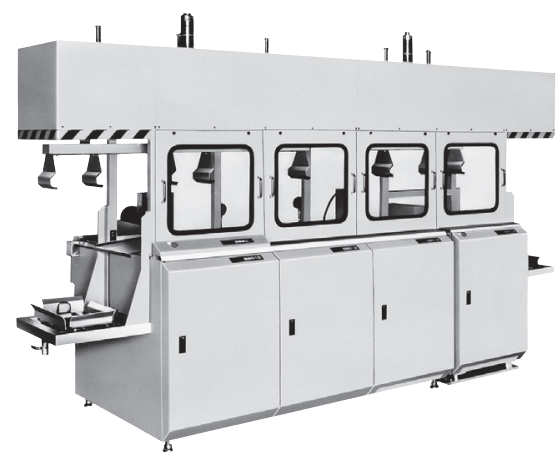

図 1 洗浄設備の外観
装置で構成されている。すすぎ工程は 2 段階に分かれる場合 もある。洗浄対象の金属部品は, 図 3 に示す搬送用のバスケッ トに収納され，このバスケットをコンベアに吊るして移送す ることにより，洗浄・すすぎ・乾燥の順に各装置を移動する。 各装置での所要時間は 4 分程度であり, 洗浄から乾燥までの 合計の所要時間は 16 分程度である。洗浄する機械部品は数 〜数十 $\mathrm{cm}$ の大きさであり, バスケットの寸法は幅 $220 \mathrm{~mm}$ ×奥行 $320 \mathrm{~mm} \times$ 高さ $250 \mathrm{~mm}$ である。

洗浄装置では, 洗浄剤が溶解した水溶液が入った槽に機械 部品を入れ，超音波による外力などを併用して，機械部品表 面の切粉や油分を除去する。すすぎ装置には水が入っており, 洗浄後の機械部品を入れ，表面の洗浄剤をすすぎ落とす。

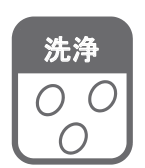

洗浄装置

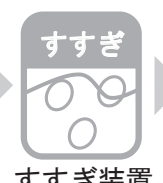

すすぎ装置

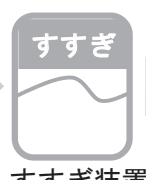

すすぎ装置

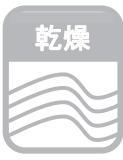

乾燥装置
図 2 洗浄設備の構成装置

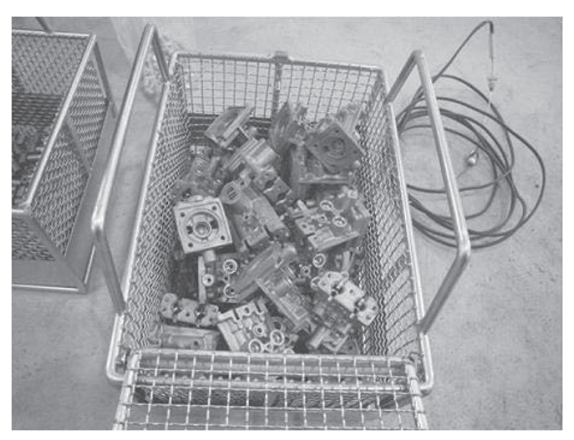

図 3 搬送用バスケットに収納された金属部品 


\section{2 従来の乾燥方法}

従来の熱風式の乾燥装置では， $60 \sim 200{ }^{\circ} \mathrm{C}$ 程度の熱風(高 温の空気または燃焼ガス)を機械部品に吹き付けて，すすぎ 工程で付着した表面の水分を乾燥させる。乾燥を促進させる ために, モー夕駆動の回転台の上に乗せて機械部品を回転さ せ，遠心力により水切りを行う場合もある。

\section{3 洗浄剤の種類と乾燥時間}

機械部品の洗浄剂の種類は水系, 準水系および溶剤系の 3 種類に大別され，乾燥する対象物や污れの成分などにより使 い分けられている。経済産業省の平成 20 年度化学物質安全 確保・国際規制対策推進等調查報告書(工業用洗浄剂の実態 調査)によれば，平成 19 年度の工業用洗浄剂の出荷量の合計 は 135,808 トンである。水系および準水系洗浄剂の出荷量の 全体に対する割合は，それぞれ $27 \%$ および $3 \%$ でり，溶剤 系の割合は $70 \%$ でった。

各種洗浄剤の比較を表 1 に示す。溶剂系洗浄剤は，炭化水 素系, 塩素系およびフッ素系等があり, 洗浄能力が大きいも のの，人体に有毒で引火性がある。溶剤系洗浄剤が規制を受 ける法令は, 化学物質排出把握管理促進法 (PRTR 法) ・消防 法(危険物第四類 (引火性液体) ) - 毒物劇物取締法 - 労働安全 衛生法の有機溶剂中毒予防規則・大気污染防止法等がある。

これに対して, 水系洗浄剤は洗浄能力が劣るものの, 無害 で引火性もなく安全である。このため, 溶剤系洗浄剤を使っ ている工場で，污れが除去しやすい機械部品を扱っている場 合は，無害な水系洗浄剤の導入を要望する場合が多くあった。 しかし，従来の熱風方式による乾燥では，揮発性の高い溶剤 系に比べて, 水系洗浄剂では乾燥工程に時間がかかるため, 工場で水系洗浄剤を導入したくても断念する場合が多かった。

\section{4 過熱水蒸気の概要}

過熱水蒸気とは, 沸点より高い温度の乾いた水蒸気のこと である。大気圧下では, 水の沸点は $100{ }^{\circ} \mathrm{C}$ であので, $100{ }^{\circ} \mathrm{C}$ の水蒸気は飽和水蒸気であり, $110{ }^{\circ} \mathrm{C}$ や $200{ }^{\circ} \mathrm{C}$ では過 熱水蒸気である。産業用途や家庭用途では, 大気圧近傍の低 圧下で 150 〜 $500{ }^{\circ} \mathrm{C}$ の温度帯で使用されるのが一般的である。 過熱水蒸気は, 高温のガスであるため, 乾燥用途にも使用可 能である。

過熱水蒸気には以下のような特長があるため, 従来から使 われてきた熱風に替わる高機能の加熱媒体として, 近年注目 を集めている。本開発品では，この過熱水蒸気を活用するこ ととした。

高速加熱が可能である。

表 1 洗浄剤の比較

\begin{tabular}{|c|c|c|c|}
\hline 種類 & 成分 & $\begin{array}{c}\text { 洗浄 } \\
\text { メカニズム }\end{array}$ & 特徵 \\
\hline 溶剤系 & $\begin{array}{l}\text { トリクロロ } \\
\text { エチレン } \\
\text { など }\end{array}$ & $\begin{array}{l}\text { 污れを } \\
\text { 溶かす }\end{array}$ & $\begin{array}{l}\text { ·洗浄能力が大きい。 } \\
\text { ·乾燥が早い。 } \\
\text { ・人体に有毒である。 } \\
\text { · 引火性がある。 } \\
\text { ·購入コストが高い。 }\end{array}$ \\
\hline 水系 & $\begin{array}{c}\text { 界面 } \\
\text { 活性剤 }\end{array}$ & $\begin{array}{l}\text { 污れを } \\
\text { 剥がす }\end{array}$ & 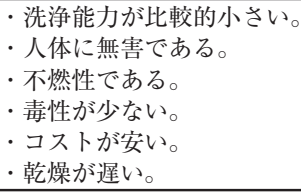 \\
\hline
\end{tabular}

温度ムラなく均一に部品を加熱できる。

内部の加熱が早い。

無酸素状態にできる。

\section{5 過熱水蒸気の乾燥メカニズム}

図 4 (a)に示すように, 大気圧下での過熱水蒸気による加 熱のメカニズムは，次の 2 工程に分けられる。

(1)工程 1 (物体の表面温度が常温から $100{ }^{\circ} \mathrm{C}$ 未満の状態)： 加熱室に挿入されたばかりの低温の物体に過熱水蒸気が 接触すると, 過熱水蒸気が物体の表面に凝縮し水が付着 する。このとき, 水蒸気は大量の凝縮潜熱を放出するた め, 物体は急速加熱される。

(2)工程 2 (物体の表面温度が $100{ }^{\circ} \mathrm{C}$ 以上の状態)：物体の表 面温度が沸点に達すると，温度を沸点に保ったまま，表 面に付着した水が蒸発を始める。水がすべて蒸発すると, 物体は沸点を超える温度に上昇する。これらの水分の蒸 発と物体の昇温には，過熱水蒸気の顕熱のみが消費され， 過熱水蒸気は沸点より高い温度で排気される。ここで, 顕熱とは，物質の温度変化に伴う熱である。また，潜熱 とは, 温度は一定のまま, 蒸発や凝縮などで物質の状態 が変化する際に伴う熱である。

過熱水蒸気の伝熱の特徵は工程 1 にあり, 伝熱効率のよい 凝縮によって物体に大量の熱を伝えるため, 物体の急速な昇 温が可能となる。一方, 図 4 (b) に示すように, 熱風による 加熱ではこの工程 1 がない。このため, 過熱水蒸気による加 熱の所要時間は, 熱風による方式に比べて, 金属の場合は 5 分の 1 ～ 10 分の 1 程度になると言われている。なお, 過熱 水蒸気は特定の波長域で電磁波を発生するため, 熱風での伝 熱ではみられない輻射伝熱も加味される。

\section{6 開発の目的}

水系洗浄剤を用いた洗浄において，すすぎ工程で機械部品 の表面に付着する水分の乾燥に時間がかかるため，水分を短 時間に乾燥できる技術が求められていたが，過熱水蒸気を活 用すれば，蒸発しにくい水分の乾燥が短時間に行える。そこ で，洗浄後の金属部品を短時間で乾燥できる過熱水蒸気式高 速乾燥装置を開発することとした。

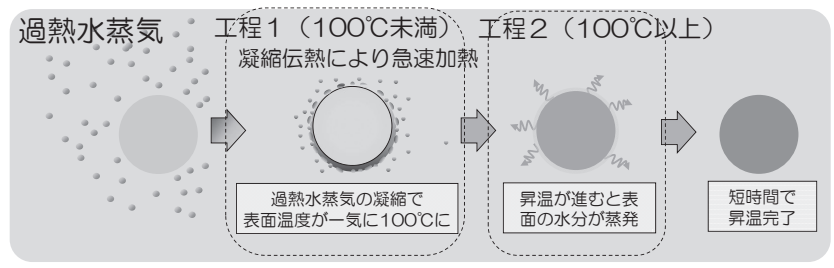

（a）過熱水蒸気

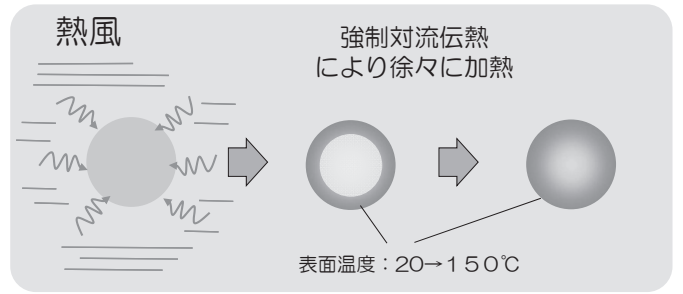

（b）熱風 


\section{3. 開発内容}

\section{1 開発品の構造}

開発品の構造を図 5 に示す。供給された常温の水は, 軟水 器で不純物を除去した後に, 電気ボイラで加熱されて蒸発し 約 $100{ }^{\circ} \mathrm{C}$ の飽和水蒸気となる。この飽和水蒸気は, 過熱器の 中の電気ヒー夕で加熱され, $400{ }^{\circ} \mathrm{C}$ 程度の過熱水蒸気となる。 さらに, この過熱水蒸気は乾燥室に導かれる。この乾燥室の 中には機械部品が収納されており, 過熱水蒸気を照射するこ とで部品が乾燥される。乾燥後の過熱水蒸気は, 乾燥室外に 排気された後に, 冷却装置で外気と熱交換して凝縮し, ドレ ンとして排出される。なお, 乾燥室内の過熱水蒸気の温度は, 断熱膨張するため, $250{ }^{\circ} \mathrm{C}$ 程度になる。

\section{2 開発課題}

開発にあたって解決すべき技術的課題は，以下の 5 点で あった。

(1)乾燥時間の制約

実際の工場の洗浄設備のタクトタイムは 3 分程度であるた め, 開発品の乾燥時間も 3 分以内にする必要がある。

(2)複雑形状部品の乾燥

従来の熱風による乾燥方式でも，平板や丸棒などの単純な 形状の部品は, 3 分以内での乾燥が可能であった。しかし, 図 6 に示す凹凸の多い複雑な形状の部品では, 乾燥に 10 分

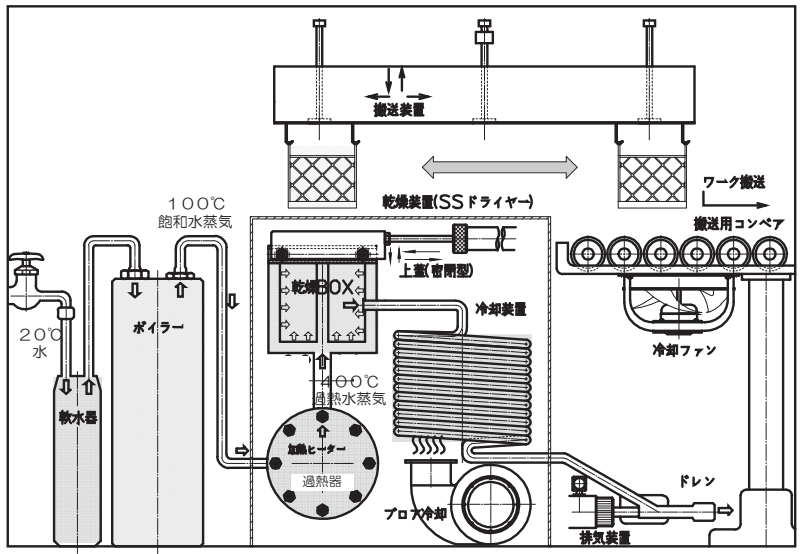

図 5 開発品の構造

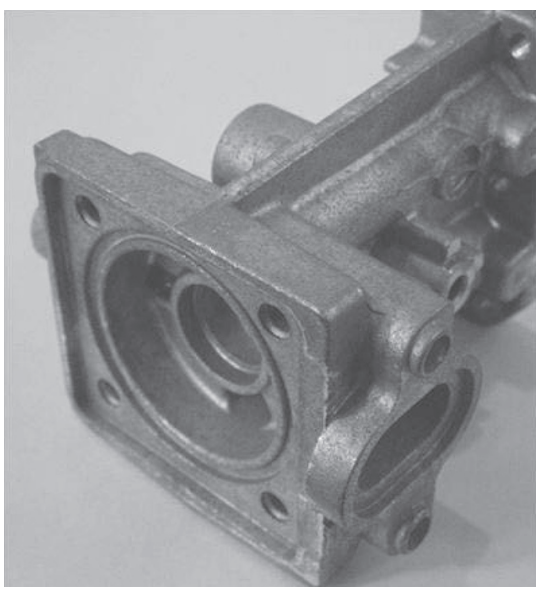

図 6 複雑形状の金属部品
から 1 時間以上を要する場合があった。具体的には，袋穴と 呼ばれる貫通していない穴や複雑形状の部品の凹部に保持さ れた，水滴の乾燥に時間を要する。このため，複雑形状の部 品でも 3 分以内に乾燥が可能とする必要がある。

(3)蒸気流量の最小化

一般に，蒸気流量を大きくすれば，機械部品に供給する熱 量が大きくなるため, 乾燥時間を短縮できる。しかし, 蒸気 流量を大きくすると，エネルギー消費量が大きくなると共に, 装置のコストおよび寸法が大きくなる恐れがある。このため, 蒸気流量を可能な限り小さくする必要がある。

(4)蒸気分布の均一化

蒸気流量を小さくすると, 乾燥室内の局所に蒸気が行き渡 らず,一部の部品で乾燥不良となる場合があり, 特にバスケッ トの隅の部分が乾きにくい傾向があった。このため, 蒸気流 量を可能な限り小さくすると同時に, 乾燥室内の蒸気の分布 を均一にする必要がある。

(5)蓋の開閉による乾燥装置内の温度低下

実際の乾燥工程においては，乾燥装置の蓋を 1 分程度開放 して, 乾燥後の部品を乾燥装置から搬出した後に, 次の乾燥 前の部品を乾燥装置内に搬入する。この蓋が開いた際に，乾 燥装置内の過熱水蒸気が外気に放出されるため, 乾燥装置内 の温度は瞬時に低下する。この乾燥装置内の温度低下は乾燥 能力の低下に繋がり, 乾燥時間が延びることになるため, 蓋を 閉めた後に乾燥装置内の温度を急速に回復させる必要がある。

\section{3 開発のポイント}

開発にあたっては，乾燥室の試作および乾燥試験を繰り返 し, 問題点を洗い出すと共に構造の最適化を行った。図7に 示すように，乾燥室の内部に，バスケットを隙間なく収容す る箱状の収容体を設ける。この収容体は, 断面が長方形のパ イプを格子状に組み合わせて形成されている。このパイプ内 に過熱水蒸気を流し，パイプの噴出孔から，バスケットに過 熱水蒸気を吹きつける。過熱水蒸気を周囲に拡散することな く，バスケット内の部品に近接して吹きつけることがきるの で，部品の乾燥性能を向上させることが可能となった。また， 噴出孔を収容体の全面に設けているので, 乾燥しにくかった バスケットの隅の部品にも十分な量の過熱水蒸気を吹きつけ ることが可能となり, バスケット内の部品をくまなく乾燥さ せることが可能となった。また, 過熱水蒸気が周囲に拡散せ ず，部品の乾燥に無䭾なく過熱水蒸気が消費されるため, 蒸 気量の最小化も可能となった。

また, 収容体の下部に電気ヒータを設けた。この電気ヒー 夕で急速加熱することにより, 乾燥室内の温度が瞬時に低下 しても, 乾燥室内の過熱水蒸気を急速昇温できる。このため, 乾燥室の蓋の開放後に, 乾燥性能の確保が可能となった。

\section{4. 評 価}

\section{1 乾燥時間}

図 6 および図 8 のような多様な材質(アルミ，真鍮および 鉄) および多様な形状の部品を使用して乾燥試験を実施した 結果, どのような部品でも 3 分以内で乾燥できることを確認 した。図 9 は, 熱風で 4 時間かかっていた $12 \mathrm{~kg}$ の部品を過 熱水蒸気で乾燥した結果，3 分に短縮できた例である。 


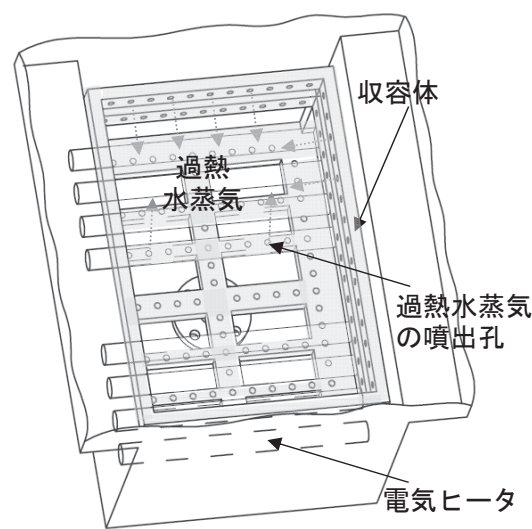

(1)部品を収納していない状態

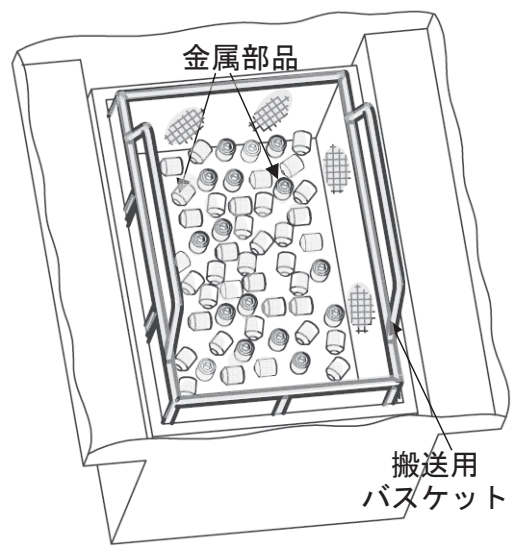

(2)部品を収納した状態

図 7 乾燥室の構造

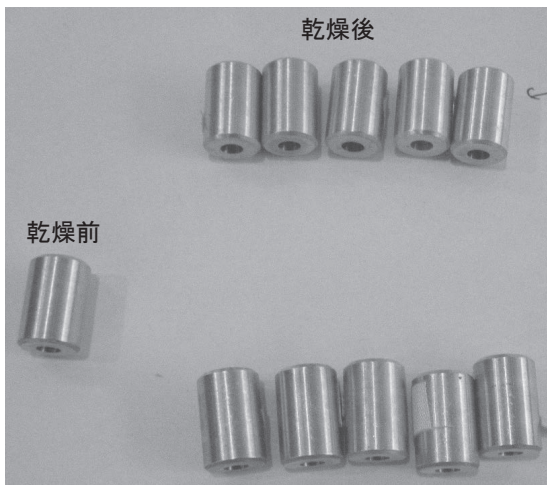

図 8 乾燥前後の金属部品

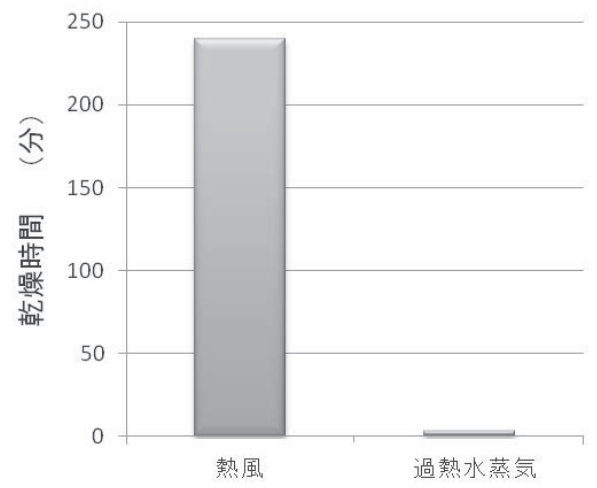

図 9 複雑形状金属部品の乾燥時間の試験結果

\section{2 表面性状}

高温の過熱水蒸気が金属部品に接触すると，部品表面に染 みが発生したり，寸法が変化する懸念があった。図 8 のよう に, 乾燥前後の部品の染みおよび寸法を評価した結果, 染み の発生および寸法の有意な変化は確認されなかったため, 過 熱水蒸気により乾燥しても部品に影響を与えないことが分 かった。また，過熱水蒸気中の不純物が金属部品に付着物を 残す懸念もあった。表 2 のように, 乾燥後の部品の表面の付 着物および付着油分を分析した結果，検出限界以下であり， 付着物は確認されなかった。

\section{5. 開発品の仕様}

\section{1 構成と仕様}

図 10 および表 3 に，開発品の外観および仕様を示す。開 発品は，洗浄設備に組み込まれており，着色した装置が開発 品である。洗浄およびすすぎの装置は従来と同じである。乾 燥装置の背面には, 小型の電気ボイラが設置されており, 電 気ボイラで発生したゲージ圧 $0.1 \mathrm{MPa}$ の約 $120{ }^{\circ} \mathrm{C}$ の飽和水蒸 気が乾燥装置本体に供給される。供給された飽和水蒸気は,

表 2 乾燥後の表面性状の分析結果

\begin{tabular}{|c|c|c|c|}
\hline 洗浄液の種類 & 試料 & $\begin{array}{c}\text { 付着物量 } \\
(\mathrm{mg} / \text { 個 })\end{array}$ & $\begin{array}{c}\text { 付着油分量 } \\
\text { (mg/個) }\end{array}$ \\
\hline \multirow{3}{*}{ 水+中性洗剂 } & $\begin{array}{c}\text { 製品 } \\
\mathrm{a} \\
\end{array}$ & $<0.05$ & $<0.01$ \\
\hline & $\begin{array}{c}\text { 製品 } \\
\mathrm{b} \\
\end{array}$ & $<0.05$ & $<0.01$ \\
\hline & $\begin{array}{c}\text { 製品 } \\
\mathrm{c} \\
\end{array}$ & $<0.05$ & $<0.01$ \\
\hline $\begin{array}{c}\text { 水+アルカリ } \\
\text { 洗剤 } \\
\end{array}$ & $\begin{array}{c}\text { 製品 } \\
\mathrm{d} \\
\end{array}$ & $<0.05$ & $<0.01$ \\
\hline
\end{tabular}

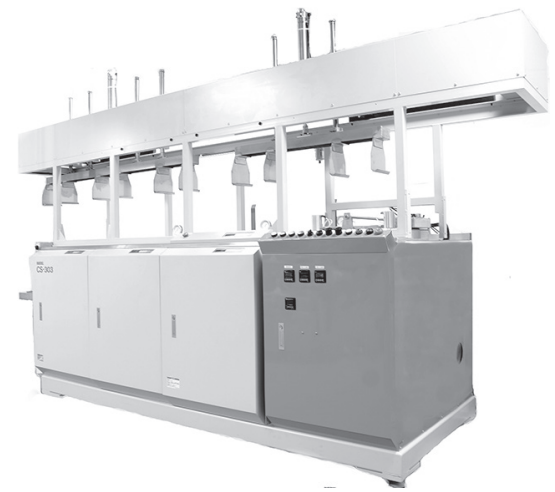

図 10 開発品を組み込んだ洗浄設備

表 3 開発品の仕様

\begin{tabular}{c|c|c}
\hline 項目 & 単位 & 開発品 \\
\hline 外形寸法 & $\begin{array}{c}\text { 幅 } \times \text { 奥行 } \times \text { 高さ } \\
\mathrm{mm}\end{array}$ & $606 \times 1,360 \times 1,010$ \\
\hline 内容量 & $\mathrm{L}$ & 20 \\
\hline 電源容量 & $\mathrm{kW}$ & $220 \times 320 \times 250$ \\
\hline バスケット寸法 & $\begin{array}{c}\text { 幅 } \times \text { 奥行 } \times \text { 高さ } \\
\mathrm{mm}\end{array}$ & $750 \sim 250$ \\
\hline 蒸気量 & $\mathrm{kg} / \mathrm{h}$ & $800 \times 1900$ \\
\hline $\begin{array}{c}\text { 過熱水蒸気温度 } \\
(\text { 乾燥室内 })\end{array}$ & ${ }^{\circ} \mathrm{C}$ & $\mathrm{AC} 200 \mathrm{~V}$ 三相 \\
\hline 据付面積 $($ ボイラ含む $)$ & 幅 $\times$ 奥行 $\mathrm{mm}$ & \\
\hline 使用電源 & - &
\end{tabular}


乾燥装置内の電気ヒータで再加熱されて $400{ }^{\circ} \mathrm{C}$ 程度の過熱水 蒸気となって乾燥室内に供給され, 部品の乾燥に使用される。

\section{2 特 長}

開発品には, 従来の熱風方式と比較して, 以下の 3 点の特 長がある。

(1)乾燥時間の大幅短縮

従来の熱風方式では，形状が複雑な機械部品では，部品の 凹部にたまった水が蒸発しにくいため, 乾燥に 10 分〜 4 時 間を要していた。本開発品では, 過熱水蒸気を機械部品に照 射することで, 寸法が数 $\mathrm{cm}$ の金属部品を数百個単位で 3 分 以内の乾燥が可能となった。

(2)高い安全性の実現

従来の有毒で引火性のある溶剤系の洗浄剤を使用する場合, 洗浄ラインを爆発しにくい特殊な「防爆構造」にする必要で あった。本開発品の導入により, 引火性や毒性がない水系洗 浄剂の採用が容易になり，洗浄ラインを簡易な構造にできる と同時に，工場の作業環境を安全にできる。

(3)洗浄剤コストの削減

本開発品の導入により, 従来は工場の負担であった溶剂系 洗浄剂の購入コストを削減できる。また, 工場 1 件あたりの 溶剂系の洗浄剂の消費量は，年間 $1 \sim 10$ トン程度である。
このため, 本開発品の導入によって水系洗浄剂を使用するよ うになれば，工場 1 件あたり年間 1 〜 10 トン程度の溶剤系 洗浄剤の使用を取りやめることができ，年間 $500 ＼mathrm{~ 5,000 ~ 千 ~}$ 円程度の洗浄剤の購入コストの削減が可能となった。

\section{6. 環境負荷の削減効果}

前述の経済産業省の報告書によれば，溶剂系洗浄剤の平成 19 年度の全国の年間出荷量は 94,574 トンであった。そのう ちの $1 \%$ ， 本開発品の導入により廃止できると仮定すれば, 全国で 1,000 トン程度の溶剂系洗浄剤の使用を取りやめるこ とができる。なお，溶剤系洗浄剤を洗浄設備に充填する際や 使用済みの洗浄剂を廃裹する際には, 相当量の洗浄剂が大気 中に放散されると言われている。

\section{7. おわりに}

本開発品は，洗浄機械および工作機械の中堅メーカーであ る株式会社 CJV インターナショナルから, 平成 24 年 11 月 に「SS ドライヤー」の商品名で発売された。今後は，工場 の洗浄ラインを対象に普及を図ることで，工場の環境性向上 およびコスト削減に貢献したい。

(Received May 29, 2015) 